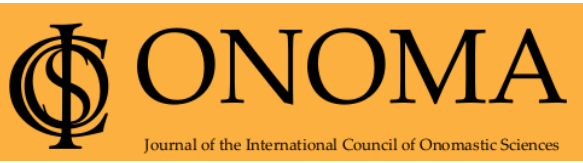

Onoma 56

Journal of the International Council of Onomastic Sciences

ISSN: 0078-463X; e-ISSN: 1783-1644

Journal homepage: https://onomajournal.org/

\title{
Dynamics of the Anthroponymic System - An introduction
}

\section{Anna Choleva-Dimitrova*}

Onomastics Department, Institute for Bulgarian Language "Prof. Lyubomir Andreychin", Bulgarian Academy of Sciences, Sofia, Bulgaria

To cite this article: Choleva-Dimitrova, Anna. 2021. Dynamics of the Anthroponymic System: An introduction. Onoma 56, 9-13. DOI: 10.34158/ONOMA.56/2021/1

To link to this article: https://doi.org/10.34158/ONOMA.56/2021/1

(C) Onoma and the author.

\section{Article history}

Received on 12 November 2021.

Final form accepted on 16 November 2021.

Published online on 13 December 2021.

* Contact: Onomastics Department, Institute for Bulgarian Language "Prof. Lyubomir Andreychin”, Bulgarian Academy of Sciences, 52, Shipchenski prohod Bld., Sofia BG1113,annacholeva@gmail.com 


\title{
Dynamics of the Anthroponymic System - An introduction
}

\author{
ANNA CHOLEVA-Dimitrova
}

The articles included in the thematic section of this volume of Onoma are dedicated to the changes in or the dynamics of anthroponymic systems. Anthroponymic systems in all countries undergo changes through the influence of various factors. By analyzing official (conventional) anthroponyms (predominantly personal names and family names), as well as nicknames, trends in the changes in the contemporary anthroponymicon are shown. At the beginning of the 21st century, the changes taking place in anthroponymic systems, especially in Europe after 1989, have been highly dynamic. In addition to the dynamics of European anthroponymicons, an object of attention here is the issue of personal names in communication processes, as well as the place of personal names in bilingual environments. Examining anthroponymics diachronically and synchronically, we have also run across issues concerning naming in various ethnic communities. Upon researching anthroponymics nowadays, we must also recognize the internationality of the processes, which has been facilitated by the development of new technologies and the globalization of the modern world.

The themed part of this issue of Onoma includes nine articles.

The first article, by Mariann Slíz and Tamás Farkas, is dedicated to the dynamics of the contemporary Hungarian anthroponymic system. The authors examine a period over the last three decades. They focus their attention on two aspects: the methods of development of the given inventory of names and the dynamics of change in the internal structure of names. They discover some specific characteristics of the naming of newborns in Hungary. It is noted that there has been a significant change in the motivations for naming. Today's parents are inclined to name their children with non-traditional, unique names. The authors find that, according to the linguistic origins among newly accepted personal names, names of both Hungarian and foreign origins are encountered. Two categories of names are observed: invented and non-invented. The final part of the article examines the dynamics of the changes in the name stock on the basis of population statistics from the last decades. Within it, they compare the 100 most popular male and female names among newborns and in the entire population. 
The second article is by Milan Harvalík and Iveta Valentová. It examines trends in the development of contemporary anthroponomy in Czechia and Slovakia. The authors note that substantial changes have taken place in the system of personal names in Czechia and Slovakia, especially after the change of political regime in 1989. The aim of the research is to show the changes, characteristic features, and trends in the development of the official anthroponymicon in the two countries from the time of the big political changes in Europe in 1989 to the present day. The first part is dedicated to personal names, with attention also given to some of the innovations in the anthroponymic system - unisex names, for example. Following this is a presentation of specificities in the formation of family names in the Czech and Slovak languages. Particular attention is given to a pronounced trend in both languages - for women to register two family names when getting married. In conclusion, it is noted that the period after 1989 is characterized by a more intensive internationalization in comparison with the previous period. Legal changes have allowed two personal names to be recorded in the register in the Czech Republic, and up to three personal names in the Slovak Republic. The citizens of both countries are more inclined to register the names of their children using foreign variations on the orthography, which in some cases have become more frequent than their traditional forms.

The article by Anna Choleva-Dimitrova, Maya Vlahova-Angelova, Nadezhda Dancheva, and Gergana Petkova is devoted to the dynamics of the Bulgarian anthroponymic system in the period between the years 2007 and 2014. This research traces the dynamics of personal names with a single reference, representing the periphery of the Bulgarian anthroponymicon, in the capital of Sofia in the period from 2007 until 2014. Approximately half of all names have only one reference. Singular cases reveal the dynamics in the system of personal names in two directions: they show the names that are leaving the Bulgarian anthroponymicon (primarily traditional personal names), as well as the names - primarily foreign - entering the Bulgarian anthroponymic system. The movement in the stock of foreign anthroponyms with a single reference is two-directional: names are flooding in, mainly from Western cultures, while at the same time, the share of typically Russian names, which were until recently preferred, is decreasing. New anthroponyms are usually produced from existing names by using a less standard or a previously unrecorded word formation. Naming creativity is less practised with male personal names, where traditional naming is preserved to a greater degree.

The next article is by Adelina Emilia Mihali, who examines anthroponymic changes in northern Romania from a sociological standpoint, in the commune of Certeze, Satu Mare county, from where more than $50 \%$ of the population has emigrated. She studies the influence of migration on innovations in first names and on the decoding of the sociolinguistic mechanisms that are the basis 
for name choices. The period under investigation includes the beginning of the migration, the period of growth in migration, the economic crisis, and the remigration of emigrants. The main issues concerned involve the dynamics of anthroponymic preferences during the period between 2000 and 2020 in the Certeze commune. Attention is given to the predominant types of names according to structure, origins, and semantics, as well as to the motivations in naming practices.

The fifth article, by Mirjana Petrović-Savić, concerns nicknames from the Jadar region. This research is based on a corpus of approximately three hundred personal nicknames collected in several villages in Jadar (Tekeriš, Pomijača, Badanja, Sipulja, Ribarica, and Trbosile). The nicknames, collected through fieldwork, belong to young and old people. All the nicknames that the local people remembered and wanted to mention were included. The article analyses the possibilities for the semantic classification of personal nicknames and examines the most common motives for the bestowal of nicknames. Another aim underlying the research of this type of anthroponym is to preserve certain appellatives that are no longer used beyond this onomastic category. A list of the personal nicknames collected is included.

The article by Oksana Dobrovolska is devoted to the study of the etymological composition and functional differentiation of the semantic group of names of metalworkers. The vocabulary is distributed into three parts with regards to its origin or to the origin of the word-stems: native words, loanblends, and loanwords. The vocabulary is differentiated into three groups according to a functional principle: occupational terms as common nouns and proper names with the functions of identification (individualization) and classification (categorization); occupational terms as proper names with the only function of identification; and occupational terms as common nouns with only the function of classification. In conclusion, the author states that the prevalence of vocabulary with the function of identification over that with the sole function of classification in a ratio of 9:1 proves the active usage of the names of metalworkers as anthroponyms in the Middle English period.

In her article, Linnea Gustafsson examines Syrian personal names in Sweden. A total of 1119 personal names are studied: 32 female and 791 male. These are names of Syrian citizens who lived in Sweden between 2014 and 2018. Their frequency is described, as well as their phonological aspects. The results show differences between female and male personal names with regard to the variations in personal names. In addition, there are similarities, as well as differences between Syrian and established Swedish personal names that may lead to a lack of acceptance of the use of Syrian personal names for naming the children of native Swedes. The reference point for the analysis is contact onomastics and the question of whether (or not) Swedish naming practices are undergoing a change due to names in contact. 
The article that follows is by Süleyman Kasap. Personal names are examined in the context of bilingualism, and the problems of minority communities are addressed. Specifically, the research focuses on Kurdish minority groups in the Turkish-ruled society. The work has two parts: the first part is devoted to bilingualism, and the second part examines the difficulties Kurds encounter when they want to have their own names in a predominantly Turkish society. Interviews with seven participants are used. The results show that the participants have had to pass through many difficulties due to their names, which are written with Kurdish letters. Consequently, they have been negatively impacted in almost all aspects of their lives because they have names that in Turkish have strange meanings or are rendered nonsensical.

The final article is by Igor Kusin. It examines the personal names of Jews from Zagreb at the beginning of the 19th century. Names from three sources are analysed: Gavro Schwarz's book The History of the Zagreb Jewish community from its founding until the 1850s (Zagreb, 1939), Jewish birth registers from 1849 to 1898, and data collected from the Israeli (Jewish) part of the old cemetery in Mirogoj. The anthroponyms are studied according to their frequency, origins, and the languages from which they were taken. Male and female personal names are examined separately, along with the etymologies, relationships, and connections between separate "civil" and individual "Jewish" personal names. 